University of Louisville

ThinkIR: The University of Louisville's Institutional Repository

Electronic Theses and Dissertations

1948

\title{
Some reactions of chloro-cyclo-hexanone and its derivatives and the synthesis of 1 chloro- 2 methyl cyclo hexene.
}

\author{
Elle Bolt \\ University of Louisville
}

Follow this and additional works at: https://ir.library.louisville.edu/etd

Part of the Chemistry Commons

\section{Recommended Citation}

Bolt, Elle, "Some reactions of chloro-cyclo-hexanone and its derivatives and the synthesis of 1 chloro-2 methyl cyclo hexene." (1948). Electronic Theses and Dissertations. Paper 1913.

https://doi.org/10.18297/etd/1913

This Master's Thesis is brought to you for free and open access by ThinkIR: The University of Louisville's Institutional Repository. It has been accepted for inclusion in Electronic Theses and Dissertations by an authorized administrator of ThinkIR: The University of Louisville's Institutional Repository. This title appears here courtesy of the author, who has retained all other copyrights. For more information, please contact thinkir@louisville.edu. 


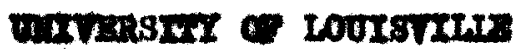

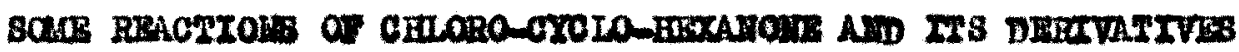

And

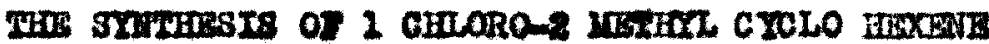

\author{
A Drsseracion

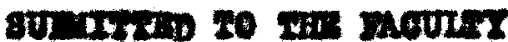

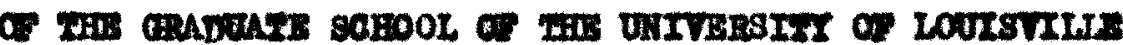

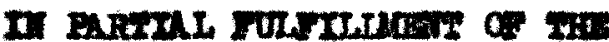

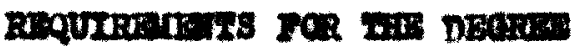

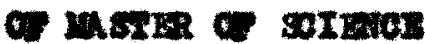

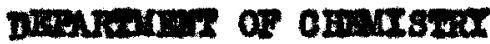

is

Din BD:

1848 
Nome of studeat

Ittle of Thesie

Approred by Reading of Gemaltteo Compered of the sollewing munere:
11. Bolt

8 can Resticas of Ohloro - Oyelo Hesanene and Its Dereivatives. and the Syntheats of 1 Chiore -

2 Lethyl cyolohoxeme.

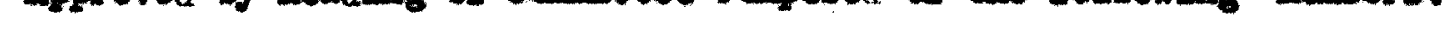

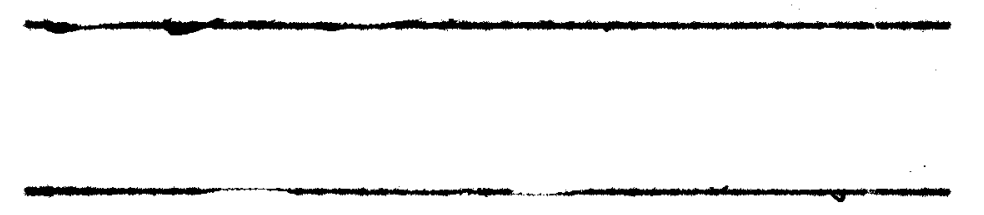

Iame of Directar

D. U. I. Bomman

Date

Auprot, 1848 


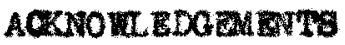

I wh to oxpreas my approofetion to Dr, Hex I. Bowan. Assiatunt Erofessor of Chanlatry, College of Axte and Sclenoes, Unirersity of Loulstille, for his oounsel and guldenoe and for his kind cooperetion in making the I1terature Researobos. Alwo to my family in South Africa, for oontributing materially in pemitting wo to complete thl w wox In the Unt ted States of Ameriea, 


\section{Puypoes}

(1) In the current 11terature on the alorination of cyelohexanone, no ovidence could be found of the phyoical constants of sertratives of the ohlorinated ocmpound, ahloro - eyclo herenone. It was thought adviabl to prepare the nore comon dertvatives of chloro - oyolo - hexanone, and to report their phyalcal conetants, both for ldentiflcation and puritication purposes.

(2) To symbestzo obloro - methyl - cyclo - hexenea. These compounds hare not yet been reported in the fiterature. 


\section{iletorlcel}

The aynthents of alloro - cyclo - hexanone was reported by F. Bbal in 1929 , by direct chlorination of oyolo - hexanone In water solution in the presence of calciua darbonate. A more offlolent procedure was reported by P. Bartlott in 1934(1). In thle nethod alrect chlorination was fiseoted in gacial acetio solution, in the precence of exuas of cyclo hexenose. By this pethod very 11 ttle high bolfing residue results. This is at present the beet method for prepartng ohloro - eyolo - hexanone. 


\section{superimental}

\section{Glortnation of Crolohexamese (2)}

A run was carried out as follows: 75 graws of eyclohexanone and 225 co. of glacial acetic acid were placed in a 500 co. Long necked flask, and Lumersed in an lce bath, 50 gram of mangenese dioxide were pleced in a round botton flack fltted wh a dropplng funnel. fllled with hydrochloric acid and delirery tube. The ohlorine was washed in sulfurte aold, and dried in glass wool, and Introduced into the cyclo bexanone through a cap111ary tube. The reaction was started and the chlorine introduced in amall bubbles, while the reaction mixture was shaken throwghout. The chlorine was absorbed very rapidly. Arter all the ahlorino has been introduced (14 11tera), the mixture pas at once reculm distlled. All fractions bolling below the maln Iraction $\left(80^{\circ}-68^{\circ}, 14\right.$. $105^{\circ}-110^{\circ}-35$. $)$ were rotumed to the reaction flakk, and used for another run. The eraction bolling $205^{\circ}-110^{\circ}, 35$ mas collected. whe product was chloro - cyclo - hexanone.

II. Phrsto8l Constante of Oblorocrclohermone

(a) B. P. $89^{\circ}-80^{\circ}-14$ ma.; $108^{\circ}-110^{\circ}-30 \mathrm{~mm}$.

(b) Rerractive Index = $1.4 \mathrm{gl}$

(ब) Denatty $D_{01}^{25}=1.159$ 
III. Quentitetite Analysis of Chlordae in Chlono - CycloHexenone - Stepanorf Yethod

Experimentia: Conneot a 300 cc. Xjaldahl Ilak wi th short condensar, wose tube is perfeotly dry. Olemp over who geuze, cotered with a thin sheot of asbestos. Introduce 0.2 grams (w) of chlerocyolohexanone into the Kjeldahl Mack, and add (156 $\times$ w) co, of 1sopropylaloohol. Warn with a Plane until the substance is dissolvad. Introduce through the condenser (19.5 X W) grams of sediun. This operation should extend orer at least fiftean alnutes. Keep the solution at reflux temprature for at least one hour after the last of the sodium has been Introduceà. Then cool, nà allute wth $50 \mathrm{co}$, of water through the condenger. Aaldify the solution wh thitrio neld; will derinitely actalc. Then add a measured amount (exces) of stundardized silver nitrate $\left(Q_{1}\right.$ N) solution. Dotermane

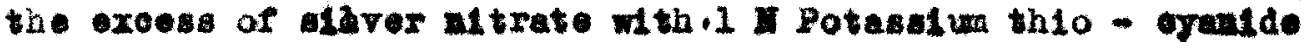
solut1on, using amont ferrte alon ta indicator.

Caloulated for chlortne in $0_{6}{ }_{9} 0 \mathrm{Cl}=26.5$

$$
\text { Found } 26.3
$$

IV. Preparation of Dertret1res of Chlore - Cyclo-Fesanone (6)

(a) Proparation of the semicarbdzone: 5 grane of the chloro oyclo - hexanone was wixed wh 5 grams of 1sopropyl aloohol, in $850 \mathrm{cc}$. Nlask. A solution of 6 gram senicarbozlde 
bydrochloride and 8.0 grams of sodiun acetate dissolved in 100 cc. of water was added. The alxture was ahaken Vigorously, and loft to stand orernight at roow teaperature, and then flitered. The solld sealcarbazono obtained was purifled by reoryatallization from alcohol.

Reault: A wite solldi U. P. $288^{\circ}$.

Calo. for $\mathrm{Cl}_{2}$ in $\mathrm{C}_{7} \mathrm{H}_{12} \mathrm{OH}_{3} \mathrm{Cl}=18.7 \%$. Found $\mathrm{Cl}_{8}=16.8 \%$.

(b) Preparation of the of Dlnitro - phearl - hydrozonet (7)

4 mixture of 1.5 grams of dint tro phonyl hydroztne, 200. of chloro - cyclo hoxanone and $100 \mathrm{co}$. of 1apropyl alcohol to brought to bolling. The Name 18 removed, and 200 . of conoentrated hydrochlorte aold 18 added. The color changes, and a yellow solld separates out on cooling. Resultst A yellow solid: A. P. $150^{\circ}$. Oalc. for $\mathrm{Cl} \mathrm{in} \mathrm{C}_{28} \mathrm{H}_{15} \mathrm{H}$ OL $=15.9 \%$ Touma $=25.6 \%$ 


\section{Part II}

The Syathests of 1 Chloro - 8 Yothyl Cralo Hexeng

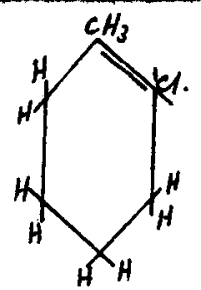

Theory and Discusston: The reection of 2 chloro oyclo hexanone and mothyl megnesi un 10a1de (Crlgnard reagent) and the subsequent hydrolysts of the addition compound has already been decertbed. 6 The reaction proceeds anothly, and yids ranglag from 55 have been reported. The produet wa I methyl - 2 - chloro oyolo heranol.

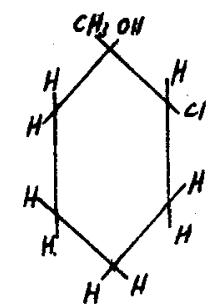

If thls eompound be dehydrated, it would yteld the dealred produet, 1 Chloro - 2 methyl cyclohexene. Tse reaction however, could take place in two ways, ylalding the 1 someric coupound 1 ehloro 2 - mothyl cyclohexene (a) and, or, 1 chloro 2 methyl 8,3 eyclohexene (b)<smiles>CC1CCCC(C)C1(C)N</smiles>

(a)<smiles>CC1CCCCC1N</smiles>

(b).

differing in the position of the double bonds. It was ougsested to dehydrate the chlohgdrin (1) with iodine. In its compound (a) the ohlorine atom wII be stable, while, in the case of compound, (b). 
the ohlorine atom wil be lablle. The different reactivities of the ahlomine atons thus offered a altable solution to this problem. II the produet of the dehydration from the chlorhydrin (1) be subjected to alnulteneous hydrolysts and oxdation by neens or sodici dichromate and sulfurto acla(5)the chlorine in compoind (a), due to 1 ts stablitty, w11 remein unchanged, wile that in compound (b) w111 be replaosd by a ketone group. After extraction of the solution wh ther, the ketone, (12 any) colld be identiflod by conventional meens. If no ketome be formed, the cahyration product from tise chlorhydrin and lodine, will bo exclustrely the compound $(a), 1$ oinloro: 2 methyl cyatahexwe. Reectionst The reactions teke plece in the following nannert

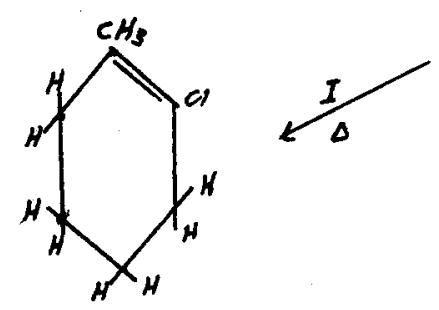

1 ohloro - 2 methyl

ayolo hexene

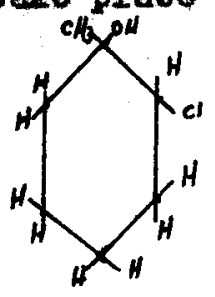<smiles>C[14CH2]C[14CH2]</smiles>

1 chloro ${ }^{A}-2$ methyl

cyclo hexene

\section{Experimental:}

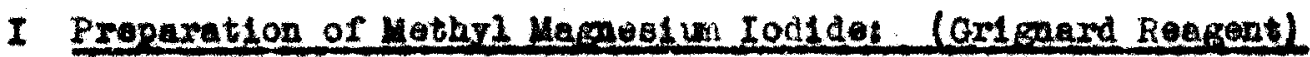

The conventlomel mothod of proparing the Grignard Reagent was wed(8)5 grems of magnealum tumings were placed in a three necked flasx, fltted wh a stirrer and an efflelont repux oondenser. A rntxture of 30 grase of methyl jodlde in $70 \mathrm{co}$. dry ether was 
introduced slowly through a dropping funnel, so as to keep the mixture bolling continually. This ylelds methyl magnest un lodide.

II. Preparation of 1 Lethyl 2 Chloro Cyclo Hexanol:

The Mak in whth the GFlgnard solution was prepared was surrounded by 100, and eooled to $0^{\circ}-5^{\circ} 0,5.5$ grams of ahloro cyclo hexanone was dietolred in $50 \mathrm{oc}$ of dry other, and cooled to $0^{\circ} \mathrm{o}$. The solution was added throw the dropplage rumal, and vigorous atirring was maintained. The product was then hydroiguted wh $10 \%$ sultume actd, walch has alco been cooled to between $0^{\circ}-5^{\circ} \mathrm{C}$. The solution was extracted 1th ether, and the ethor salution wahed wth sodilu carbonate solution, and then dried with sodium sulfate. The yield was 1 ios of a product B. P. $90^{\circ}, 32 \mathrm{me}, x_{\mathrm{D}}^{\infty}$ 1.4610. Reported for 1 mothyl 2 obloro oyclohexanol A. P. $75-75^{\circ}, 15 \mathrm{~m}, \mathrm{n}_{\mathrm{D}}^{10} 2.4 \mathrm{En}$.

\section{Eymthesis of 1 Chloro 2 Methrl Cyclo Hexene}

The rosetion wes oarmed out in a 50 ce. three necked llask, fltted wth rorlux condenser(8). The 1 methyl 2 ahloro cyolohexanol (3 grams) was introduced, and heated to $85^{\circ}$ on a water beth. A cryotal of lodine was added, and the mixture held at $95^{\circ}$ for at least thirty minutes. The colution was then racuin distilled, and the freotion B. P. Ee 86 $6^{\circ}-10$ man we collected.

It was purifted by washiag with water, wh1 ch removed the unohanged loahol, and some lodine. The product had the following propertiest (1) Insoluble in water 
(2) Refrective Index $n_{b}^{85}=2.4848$

(3) Tost for unsaturation:

(a) Decolorizes Brontine water.

(b) Precipitates mangenese dioxide from potasstum permangeante solution.

(4) Chlorine Analysts:

Celoulated for $\mathrm{Cl}$ in $\mathrm{C}_{7 \mathrm{H}} \mathrm{H} \mathrm{CL} .=27.0 \%$

Found $=26.7 \%$

To distingutah between 1weners in the produot obtained in II.

the followis procedure was employed: The reaction wes carried out

as follows(5):1 gran of the chlortne compond was caulatifled in 16 ce. water, with the ald of mechanteal stiwer. Two grans of sodium

dichromate was added, and the solutiai bsated to $60-65^{\circ}$. Concentrated sulfuric aeld (2.5 grame) was added orer a pertod of flve minutes, the teaperature boing kopt at $60-60^{\circ}$. The solution was cooled down, and extraoted with ther. The ther was evaporated, and the realdue treated wth sent carbbetde hydrochloride.

Resul: Ho sendcarbonone wuld be obtained. The product obtained ercan the ether extract in the abore procedure, still gave a posttive test for chlorine applying quelitative procedures. Thls proves that the chlorine was not removed, and therefore is bound fimly to the ring. The gleld was over $80 \%$

Conclusiont The produot of dehydration of 1 mothyl 2 abloro oyclohexanol (1) Wth lodine etres the product 2 chloro 2 methyl obelo hexene (11), thus,

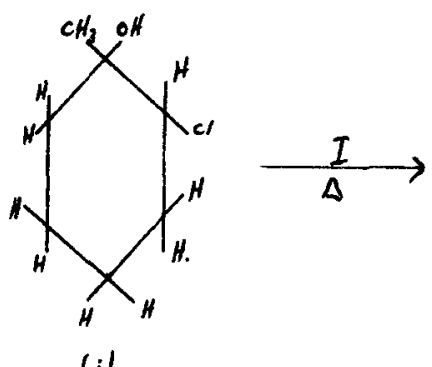

(i)

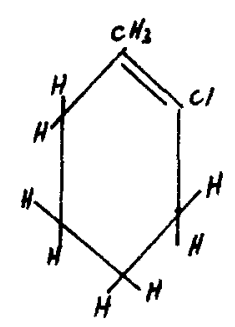




\section{Concluelonet}

The ahlorination of cyolo - hexanone has beca carried out, and cerlratives of the ehlorinated compound prepared. The physlaal constants of these derivetives has been roported in this wort. A syntheal has boen derlsed for the preparation of 1 inethyl 2 ohloro cycle hexene in high yleld, whloh has not yet been propared before. It has also been ahow that this reaction proceed in one way only and that no iscmeric sompounds are fomed. 


\section{ArBLTEORAFir}

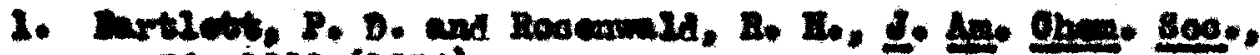
E. $1000(2034)$

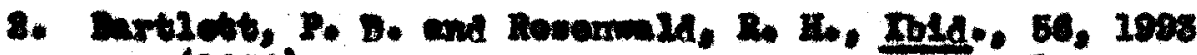
(20si)

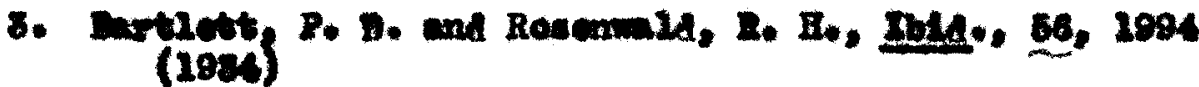

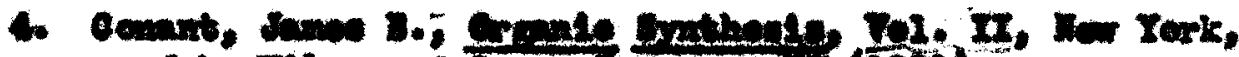

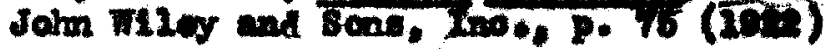

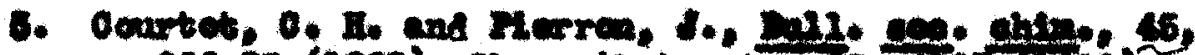

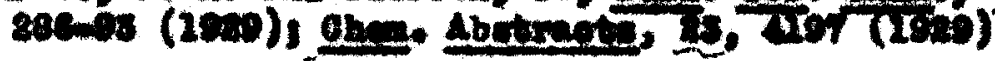

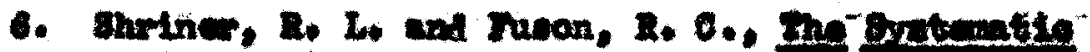

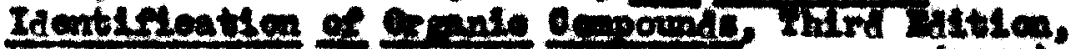

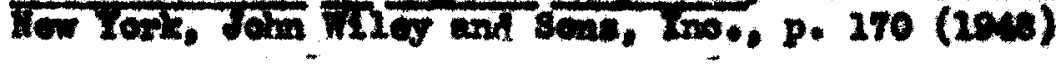

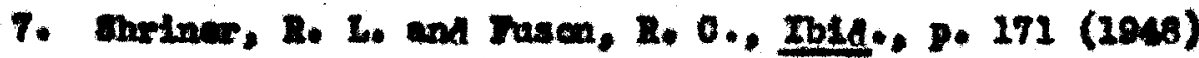

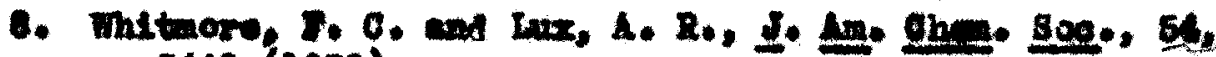
348 (1932) 